\title{
Hedging ship price risk using freight derivatives in the drybulk market
}

\author{
Roar Adland ${ }^{*}$, Hakkon Ameln and Eirik A. Børnes
}

\author{
* Correspondence: Roar.Adland@ \\ nhh.no \\ Norwegian School of Economics \\ $(\mathrm{NHH})$ and Center for Applied \\ Research (SNF), Helleveien 30, 5045 \\ Bergen, Norway
}

\begin{abstract}
We show that a fixed-maturity time-weighted Forward Freight Agreement (FFA) portfolio should be used to proxy the expected future earnings of a vessel. We investigate the corresponding hedging efficiency when using a portfolio of FFA prices to hedge ship price risk of both static hedge ratios calculated using Ordinary Least Squares estimation and the dynamic hedge ratios generated from a dynamic conditional correlation GARCH $(1,1)$ model. We find that the hedging efficiency is greater for newer vessels than older vessels and that the static hedge ratio outperforms the dynamic hedge ratio. Our work is an extension of earlier empirical work which has only considered the hedging efficiency of varying-maturity calendar FFA contracts for a single vessel age.

Keywords: Ship values, FFA, Hedging efficiency, Hedge ratio
\end{abstract}

\section{Introduction}

Due to the volatile nature of shipping markets, risk management plays an important role. The volatility of ship prices affects ship owners, banks, investors and shipyards (Kavussanos and Visvikis 2006). As ships are typically used as collateral in mortgages, any changes in ship value will affect the creditworthiness of ship owners as well as the lender's credit risk. Similarly, volatility of ship prices affects the balance sheet of ship owners, which also impacts equity investors' portfolios.

Modigliani and Miller (1958) found that, assuming a fixed investment policy and no contracting costs or taxes, a firm's corporate financing strategy is irrelevant. This implies that the firm's value is unaffected by its hedging strategy; in fact, transaction costs related to hedging would actually reduce shareholder wealth. Smith and Stulz (1985) state that a firm's hedging policy affects a firm value through taxes, contracting costs or by impacting the investment policy. In this latter framework, there are several reasons why ship owners should hedge. Firstly, it is a sector characterized by capital intensive investments, which suggests extensive debt financing where capital costs affect profits. Thus, creditors will reward lower-risk ship owners through lower interest rates. Secondly, the potential transaction costs of bankruptcy can be lowered through risk management since ships are used as collateral in debt financing. Other effects, such as potentially higher after-tax income and lower share price volatility for public firms should also be considered. For private or family owned shipping companies especially,

(C) The Author(s). 2019 Open Access This article is distributed under the terms of the Creative Commons Attribution 4.0 International License (http://creativecommons.org/licenses/by/4.0/), which permits unrestricted use, distribution, and reproduction in any medium, provided you give appropriate credit to the original author(s) and the source, provide a link to the Creative Commons license, and indicate if changes were made. 
hedging can be a solution if the owners are not able or willing to diversify their portfolio themselves.

Of course, avoiding the potential loss from decreasing asset prices through hedging asset values also implies that no profit will be gained from market upturns. Often, such asset gains can be greater than those attained from the operation of the vessel itself, which is why many ship owners rely on vessel transactions ("asset play") to make a profit in this sector (Kavussanos and Visvikis 2006). Under such circumstances, hedging is counterproductive.

While there exists a highly liquid and functioning futures markets for freight, interest rates, fuel oil and currency risk, vessel value risk is the only risk that currently cannot be managed through the use of bespoke financial instruments. However, this is perhaps the most important risk to ship owners in terms of dollar exposure (Adland et al. 2004).

Traditionally, asset diversification has been the primary tool used to manage fluctuations in the balance sheet due to volatile ship prices. Portfolios can be diversified by including ships of different sizes, ages and types. Such diversification will have an effect if the prices of the different ships are not highly positively correlated. For instance, smaller vessels have a more flexible trading pattern, and therefore their ship prices are less volatile than those of larger vessels (Kavussanos 1996). However, such fleet diversification can be costly due to transaction costs, brokers' commission fees and relatively low liquidity in the second-hand market (e.g., 86 Capesize vessels were sold worldwide in 2017 - a turnover of 5\% compared to a fleet size of 1693 vessels at year end, per Clarkson Research). In addition, specialized dry-bulk operators may not have the experience and knowledge to operate oil tankers efficiently, and vice versa (Alizadeh and Nomikos 2009). However, this can be addressed by outsourcing both the commercial and technical management to third-party managers.

There have also been attempts at creating financial derivatives based on ship values. The Forward Ship Value Agreement (FoSVA) was introduced as a cash-settled forward contract on the value of the Baltic Sale and Purchase Assessments (BSPA) by Clarkson Securities Limited in 2003 (Adland et al. 2004). However, the contracts were never traded, partly due to the lack of a clearing mechanism and associated credit risk (Adland et al. 2004). Also, marine insurers have tried to offer residual value insurance products without much success.

Given the lack of bespoke hedging instruments for ship values, it is necessary to consider the effectiveness of related financial instruments for cross hedging. The obvious candidate is the freight derivatives market, first introduced as the BIFFEX freight futures in 1985, to facilitate the management of risk associated with freight rate fluctuations (Stopford 2009). In the late 1990s the freight futures market became a more bespoke system of Over-the-Counter (OTC) forward contracts called Forward Freight Agreements (FFA). A FFA is defined as a cash-settled contract between two counterparties to settle a freight rate for a specified quantity of cargo or hire rate for a type of vessel in one (or a basket) of the major shipping routes in the dry bulk and tanker shipping sectors for a specified future time period. The underlying asset of the FFA contracts can be any of the routes (or basket of routes) that constitute the freight indices produced mainly by the Baltic Exchange or by other providers of freight market information (see Kavussanos and Visvikis 2006, and Alizadeh and Nomikos 2009, for a full 
description of FFAs and their applications for hedging). Over the past decade, the credit risk in bilateral FFA contracts has been largely removed with the introduction of central clearing, with the percentage of cleared trades rising from $12.5 \%$ in 2006 to $99.5 \%$ in 2014 (Alizadeh et al. 2015).

The possibility for cross hedging ship values with FFAs was first considered in Alizadeh and Nomikos (2012), albeit in a simplified setting where a five-year old vessel is hedged with a single-maturity FFA contract. Our contribution to the literature is threefold. Firstly, we use maritime economic theory to show that a more appropriate approach is to hedge using a portfolio of FFA contracts covering as much of its operating life as is feasible. Secondly, we examine the effectiveness of hedging ship price risk using both static and time-varying hedge ratios of a time-weighted FFA portfolio in the dry bulk market. Thirdly, we show how the FFA hedging efficiency for ship values varies with the age of the vessels and relate this to the relative importance of earnings, expectations and scrap values in vessel values. Our findings are important for several market players in the shipping industry: (i) Ship owners in the dry bulk market can benefit from cost efficient risk management of their balance sheet, increasing leverage and security against loans; (ii) shipyards can hedge against newbuilding options; (iii) providers of mortgage-backed loans with ships as collateral can benefit from securityand maturity-matching against the ship loan portfolio; and (iv) asset underwriters can use our findings to construct residual value insurance products.

The remainder of this paper is structured as follows: In Section 2 we review the relevant literature on financial risk management in shipping. In Section 3 we establish a theoretical model which connects ship prices with freight derivatives and test this relationship empirically. Section 4 presents our data and methodology. Section 5 presents our empirical results, and finally Section 6 contains concluding remarks.

\section{Literature review}

The literature on second-hand ship price formation typically uses either traditional econometric techniques to explore determinants of ship prices or focus on the timeseries properties of ship prices. In the former category, Strandenes (1984) explains the second-hand ship prices as the weighted average of spot freight rates and long-run expected time charter rates. She later included the newbuilding price as a proxy for the long-run equilibrium price (Strandenes 1986). Tsolakis et al. (2003) used a theoretical Error Correction Model to discover that second-hand ship prices are generally determined by newbuilding and timecharter rates, both in the short- and long-run in most cases. They also show that different ship sizes and segments react differently to changes in these variables. Haralambides et al. (2005) extend this supply-demand framework by also studying newbuilding prices. Beenstock (1985) argues that a supply and demand framework is not sufficient for determining ship prices, as the freight market and ship market are interdependent, which implies that the markets are jointly and dynamically determined. Rather, he claims that ship prices are priced dependent on expectations since they are real capital assets, an idea that Beenstock and Vergottis (1989a, b) developed further.

In the second category, Kavussanos (1997) examines the fluctuations in drybulk second-hand ship prices using Autoregressive conditional heteroskedasticity (ARCH) models and found that the prices of small vessels are less volatile than for larger ones. 
Kavussanos argued that this is because large ships operate in narrower markets while smaller vessels have more flexibility in their trading pattern. Alizadeh and Nomikos (2007, 2012) focus on the cointegrating relationship between vessel values and timecharter rates or FFA prices, respectively, as established theoretically by the net present value model. Cointegration is examined in the framework of Engle and Granger (1987) and the Johansen test (Johansen 1988), respectively, with empirical tests confirming that the relationship holds. Indeed, the main point of Alizadeh and Nomikos (2007) is to show that short-run deviations from the long-run relationship can be used for the timing of sale and purchase activity. In related work, Kou and Luo (2015) model the ship price-freight rate relationship allowing for structural changes and with the assumption that the freight rate follows an extended mean-reverting process. They find that the sensitivity of ship prices to freight rate changes is invariant to structural change. Alizadeh et al. (2017) introduce investor behaviour and heterogeneity among ship investors and find that momentum-driven investment tends to increase volatility, while investment demand driven by fundamentals decreases ship price volatility.

If two asset prices are closely correlated, then they are potential candidates for cross hedging. Hedging has been extensively covered within the general finance literature, with researchers initially advocating the one-to-one hedge ratio as described in Stevens (1976) and later the variance minimizing portfolio approach (Ederington 1979). Kroner and Sultan (1993) argue that the implicit assumption of constant variance in spot and futures prices of Ederington (1979) was inappropriate and suggested to estimate dynamic hedge ratios that can account for time-varying variance. While a vast literature examines the different models that can be used for calculating dynamic hedge ratios, generalized autoregressive conditional heteroskedasticity (GARCH) models - introduced by Bollerslev (1986) based on Engle's (1982) ARCH-model - appears to be the preferred method, as used by Kavussanos and Visvikis (2008) and Chang et al. (2011), among others.

Several studies have examined the hedging efficiency of freight futures or FFAs, notably Thuong and Visscher (1990), Haralambides (1992), Kavussanos and Nomikos (2000a, b), Kavussanos and Visvikis (2010), and Goulas and Skiadopoulos (2012). A general finding is that the hedging efficiency is lower than for other (commodity) markets, a feature that is most often attributed to the fact that spot freight rates represent the price for a non-storable service such that there does not exist a cost-of-carry relationship between spot and forward prices. In other words, a lower degree of comovement should be expected a priori, particularly at longer maturities. This question is naturally also related to the price discovery function and the unbiasedness of FFAs in relation to realized spot rates. Kavussanos and Nomikos (1999) found that freight futures prices ( 1 and 2 months before maturity) provide unbiased forecasts of the realized spot rates. Kavussanos et al. (2004) later conclude that the validity of an unbiasedness hypothesis depends on market characteristics, trade routes and the contract's time to maturity. Alexandridis et al. (2017) investigate the lead-lag relationships between FFAs, freight options and the physical market and find that freight futures market informationally leads the physical spot rates. Yin et al. (2017) identify the long-run and mutual causal relationship between the spot and FFA prices in a VAR and VECM framework and find that cointegration as well as exogeneous factors such as market demand and supply are dominating in their long-run dynamics. In related work, Alizadeh et al. 
(2004) studied the efficiency of hedging marine bunker price fluctuations using different crude oil and petroleum futures contracts. Using both static and dynamic hedge ratios, they found the cross-market hedging efficiency to be low compared to other markets.

The hedging efficiency of freight derivatives is also negatively affected by basis risk. Adland and Jia (2017) elaborates on the several sources of physical basis risks in the freight markets, notably differences in timing and vessel specifications. Adland and Alizadeh (2018) show that physical timecharter rates and prices of a portfolio of equivalent-duration FFA contracts in the drybulk market are co-integrated and interpret the mean-reverting differential as a proxy for differing credit risk and a convenience yield for having access to physical transportation.

Compared to freight futures and FFAs, research on the financial management of vessel value risk is lacking. Alizadeh and Nomikos (2012) establish the co-integrating relationship between five-year-old vessels and a single calendar-year FFA contract and study the corresponding efficiency of hedging ship price risk with FFAs in the dry bulk sector between 2005 and 2010. The use of a calendar-year contract for hedging purposes introduces some methodological challenges when the contract is rolled over - both in terms of artificial jumps in prices and, more importantly for this purpose, jumps in the volatility of the contract with which you hedge. This is because of the downward-sloping term structure of volatility in forward rates, as established in Alizadeh and Nomikos (2011). This will impact the estimated hedging ratios and hedging efficiency to an unknown extent. A safer approach, which we adopt in the current paper, is to generate a rolling fixed-maturity portfolio of FFAs covering a greater part of the lifespan of the ship.

Economic theory also suggests that vessels of different ages will be affected differently by freight market conditions and, consequently, require different hedge ratios. There are two effects at play here: The value of a young vessel will be more affected by longterm expectations as it has a long remaining lifespan, and less affected by the scrap value in the distant future. Conversely, the value of an old vessel will be more affected by short-run expectations (for which FFA prices are presumably good proxies) but also changes in scrap prices which cannot be hedged. It follows that, a priori, FFAs are expectedly better hedging instruments for vessels of medium age. The relationship between vessel age and hedging ratios/efficiency has not been previously considered in the literature.

In the current paper we expand on the work of Alizadeh and Nomikos (2012) along three dimensions. Firstly, we argue that if ship prices are a time-weighted average of future earnings (Strandenes 1984; Kavussanos and Visvikis 2006) then ship prices ought to be hedged not with a single FFA contract but with a portfolio of FFA contracts covering as much of the vessel's economic life as possible. Secondly, we investigate differences in the hedging efficiency of FFAs across different vessel ages. Thirdly, we consider both static and dynamic hedging strategies.

\section{Theory}

\section{Ship price formation}

The second-hand market for ships facilitates easy entry and exit of shipping investors, trading vessels worth millions of dollars "like sacks of potatoes at a country market" Stopford (2009, p.198). According to Stopford (2009), four factors influence the price 
of a vessel: freight rates, age, inflation and ship owners' expectations for the future. Any vessel can be priced according to the sum of the present value of the expected cash flows from operating the ship and the expected discounted scrap value received when the ship is obsolete (Kavussanos and Visvikis 2006). Formally, the expected return from ownership can be written as (Alizadeh and Nomikos 2007):

$$
E_{t}\left(r_{t+1}\right)=\left(\frac{E_{t}\left(P_{t+1}\right)-P_{t}+E_{t}\left(\Pi_{t+1}\right)}{P_{t}}\right)
$$

where $E_{t}\left(r_{t+1}\right)$ is the expected one period return, $E_{t}\left(P_{t+1}\right)-P_{t}$ is the expected gain in the ship price and $E_{t}\left(\Pi_{t+1}\right)$ is the expected profits from operations. Re-arranging Eq. 1, the ship price today, $P_{t}$, is:

$$
P_{t}=\left(\frac{E_{t}\left(P_{t+1}\right)+E_{t}\left(\Pi_{t+1}\right)}{1+E_{t}\left(r_{t+1}\right)}\right)
$$

where the ship price is now explained as the present value of the expected ship price in the next period, plus the operational profits in the next period, all discounted by the expected rate of return. Since this formula holds for every future period, the price at time $t$ can be written as the sum of all discounted future operational profits and the discounted residual value of the ship:

$$
P_{t}=\sum_{i=1}^{n} \frac{E_{t}\left(\Pi_{t+i}\right)}{\left(1+r_{i}\right)^{i}}+\frac{E_{t}\left(P_{t+n}^{S C}\right)}{\left(1+r_{n}\right)^{n}}
$$

where $E_{t}\left(P_{t+n}^{S C}\right)$ is the residual value in the last period, which could be either the resale price or demolition value, and the discount rate, $r_{i}$, is the rate of return demanded by the investor for holding the asset. The discount rate should reflect the uncertainty of both the future profits and the residual value generated by the ship.

The operating profit in Eq. 3 is driven by freight income and operating costs. Freight income is driven mainly by the level of freight rates, but also the utilization of the vessel, such that the ratio of laden to ballast voyages or the relative performance of the geographical region of trade. Freight rates are known to be very volatile due to the inherently volatile demand for shipping services (Kalouptsidi 2014) and the price inelasticity of demand itself due to the lack of convenient substitutes for ocean freight (Alizadeh and Nomikos 2011). Furthermore, the supply curve is widely recognized as convex, implying that the supply is elastic until the world fleet is fully utilized, and at which point it becomes quite inelastic due to the time it takes to order and build a new vessel (Stopford 2009). An inelastic and volatile demand combined with slow and inaccurate supply adjustment leads to volatile freight rates.

While vessel earnings clearly also depend on the level of operating costs (taken broadly as both voyage costs such as fuel and operating expenses such as maintenance and insurance costs), the effect of cost variations depends on the elasticities of supply and demand (Beenstock and Vergottis 1989a, b). If the demand curve is perfectly inelastic, freight rates will increase at a rate equal to the change in costs. As the demand curve in the drybulk market can be assumed to be inelastic (Alizadeh and Nomikos 2011), changes in costs will be largely offset by changes in freight rates. Hence, changes in costs will have little impact on the ship price. 
Ship prices are also affected by changes in the scrap value, which in turn depends on the steel price and the supply and demand of scrap (Stopford 2009). However, the scrap value's importance for the total ship price depends on the age of the vessel and the state of the freight market. In particular, scrap price fluctuations influence the ship prices of older vessels more than newer vessels. The rationale is that the residual value comprises more of the value, for instance, for a 20-year-old vessel than for a 5-year-old vessel, as illustrated in Eq. (3). Furthermore, during recessions, the scrap value tends to constitute more of the total value of the ships. For example, during the boom that occurred between 2005 and 2008, the "total value to scrap value"-ratio was 5 for 15-yearold Capesize vessels, however, in 2014, during the recession, the ratio had fallen to only 2 (Clarkson Research 2016).

Ship prices are also sensitive to the discount factor, which is the last component of Eq. (3) (Alizadeh and Nomikos 2012). Since it depends on such factors as the market premium, the equity beta, the risk-free rate and the cost of debt, it is quite clear that it will vary over time. However, it is reasonable to assume that these variables adjust quite slowly (Campbell and Viceira 2005), and so they are generally not the main cause of the sudden fluctuations we observe in ship prices.

\section{The relationship between FFAs and ship prices}

So far we have established that second-hand ship prices are driven mainly by expectations of future freight rates (c.f. Eq. 3), though other input variables such as expected scrap prices and the cost of capital also play a role. The suitability of a portfolio of FFAs as an instrument for cross hedging ship prices therefore depends on the extent to which the forward freight curve is a good representation of future freight rates.

This is often termed the unbiasedness hypothesis - futures prices should be unbiased estimators of the future spot freight rates (Kavussanos and Visvikis 2006, p.105). Assuming rational expectations, i.e. that it is not possible to forecast the expectation error with the information available when the expectation is formed, the unbiased hypothesis can formally be stated as:

$$
F_{t, t+i}=E_{t}\left(S_{t+i}\right)+u_{t} ; u_{t} \sim \operatorname{iid}\left(0, \sigma^{2}\right)
$$

where $u_{t}$ is an independent and identically distributed stochastic term with a zeromean and variance $\sigma^{2}$.

Kavussanos et al. (2004) tested the unbiasedness hypothesis on the basis of the cointegrating relationship between spot freight rates and FFA prices and found it to hold for FFA prices 1 and 2 months prior to maturity for all routes investigated. For longer contracts, however, the results were dependent on the routes. We note that the FFA market has since evolved away from contracts traded on single routes and settled against average spot rates towards the end of the month, such that some of these findings may no longer be applicable. Kavussanos and Nomikos (1999) and Kavussanos and Nomikos (2003) undertook similar studies for the since-defunct BIFFEX freight futures contract. In the context of using FFAs to hedge ship prices, the existence of a timevarying differential between the physical and derivative markets (Adland and Alizadeh 2018; Adland and Jia 2017) due to physical basis risk is not critical, though it will reduce the hedging efficiency of the derivative contract. 
From a theoretical point of view, if the future operating cost $\mathrm{OPEX}_{\mathrm{t}}$ is a deterministic function of time and FFA prices are unbiased predictions of future (average monthly) spot market earnings, then the expected operational profit in month $t+i$ in Eq. 3 can simply be replaced by the current FFA price with maturity $\mathrm{t}+\mathrm{i}\left(F_{t, t+i}\right)$ net of operating costs such that $E_{t}\left(\Pi_{t+1}\right)=F_{t, t+i}-O P E X_{t}$.

There are two important comments to make here. Firstly, in practice, FFAs are not traded with maturities equivalent to the full lifetime of a modern vessel. Prices from reporting agencies such as the Baltic Exchange are available only for about 5 years, and liquidity is poor for contracts beyond the first 2 years ( $n=24$ months). This means that the theoretical relationship between FFA prices and vessel prices contains a considerable residual value that cannot be hedged. ${ }^{1}$ However, in the long-run, freight rates are expected to return to some long-term average level (Strandenes 1984; Adland and Cullinane 2006). This is because of the mean reversion property of freight rates; unlike financial assets that follow a random walk (Alizadeh and Nomikos 2009). It follows that the tradable part of the FFA curve will tend to capture most of the expected variation in freight rates, with the residual being rather stable and linked to the long-term expected freight rate level. This is particularly true when the speed of mean reversion is large. Secondly, we note that the theoretical framework presented here suggests that the cross hedging of ship prices using freight derivatives should use a portfolio of (consecutive maturity) FFA contracts covering as much of the lifetime of the vessel as possible. This is particularly important due to the well-known declining term structure of volatility of FFAs, where contracts with short maturity tend to be more volatile than those further out on the forward curve. Furthermore, this also highlights the importance of vessel age on the hedging efficiency: The tradable part of the FFA curve is likely to cover more of the remaining lifespan for an older vessel. For these reasons it is important to expand on the work of Alizadeh and Nomikos (2012) as we do here.

\section{Hedging}

Let us assume that we are trying to hedge the price of a vessel (or a portfolio of vessels) with a short position in a portfolio of FFA contracts using both static and dynamic hedges.

The regression model used for estimating the static hedge ratio is as follows:

$$
\Delta P_{\mathrm{t}}=\alpha+\beta \Delta F_{t}+\varepsilon_{t}
$$

where $\Delta P_{t}$ is the percentage return of ship prices between $\mathrm{t}$ and $\mathrm{t}-52, \alpha$ is the constant term, $\beta$ is the slope coefficient (equivalent to the optimal static hedge ratio) and $\Delta F_{t}$ is the percentage return on the FFA portfolio between $\mathrm{t}$ and $\mathrm{t}-52$. We use yearly returns to capture the long-run effect of co-integration between ship prices and the FFA portfolio price and avoid the noise introduced by short-term deviations, in accordance with Alizadeh and Nomikos (2012). Note here that we adjust the yearly returns for the depreciation of the asset. ${ }^{2}$ Results for Engle-Granger co-integration tests are provided in Table 7 Appendix.

\footnotetext{
${ }^{1}$ Without loss of generality, the scrap value $P_{t+n}^{S C}$ in Eq. 3 can be replaced by a vessel residual value for values of $\mathrm{n}$ shorter than the expected remaining lifetime of the ship.

${ }^{2}$ The one-year depreciation is calculated by dividing the price difference between a 5 - and a 10 -year-old vessel by five at each point in time. For the 10-year-old ships, the price difference between 10- and 15-year-old ships is used, and so on.
} 
One problem with using weekly observations of yearly returns (i.e. overlapping return periods) is that it creates a moving average of the error term. ${ }^{3}$ This implies that the models may not be suitable for determining hedging effectiveness, as the standard errors and R-squared may be biased. As we would not have enough non-overlapping observations, we instead follow Alizadeh and Nomikos (2012) and employ the stationary bootstrap technique of Politis and Romano (1994). This technique involves resampling blocks of the original observations, with replacement, to generate new series of random paths for ship prices and FFAs and estimate the corresponding hedge ratios and hedging efficiencies. As also concluded by Alizadeh and Nomikos (2012), it turns out that the results robust to this type of mis-specifications (c.f. Table 8 in Appendix). Additionally, the Newey and West (1987) correction for serial correlation and heteroskedasticity is applied to the OLS estimation of Eq. (5). As a final test of robustness of the results we conduct an out-of-sample test, using the period from 2005 to 2009 to determine the static hedge ratios, before assessing their performance in the period 2009-2016.

The optimal static hedge ratio requires both the variance and the covariances to be constant over the examined time period. However, time-varying volatility is a common phenomenon in financial time series (Bollerslev et al. 1992). Also in shipping, Kavussanos $(1996,1997)$ find that both freight rate volatilities and ship price volatilities are time-varying.

Dynamic hedge ratios represent an approach for addressing the problem of timevarying volatility. Baillie and Myers (1991) note that the optimal dynamic hedge ratio, that is, the ratio of spot to futures that minimizes the conditional variance of the hedged portfolio returns, can be written as:

$$
b_{t-1}=\frac{\operatorname{Cov}\left(\Delta P_{t}, \Delta F_{t} \mid \Omega_{t-1}\right)}{\operatorname{Var}\left(\Delta F_{t} \mid \Omega_{t-1}\right)}
$$

where $b_{t-1}$ is the optimal hedge ratio conditional on the information available at time $\mathrm{t}$ - $1, \operatorname{Cov}\left(\Delta P_{t}, \Delta F_{t} \mid \Omega_{t-1}\right)$ is the conditional covariance of ship prices returns and futures returns and $\operatorname{Var}\left(\Delta F_{t} \mid \Omega_{t-1}\right)$ is the conditional variance of futures returns. Compared to the optimal static hedge ratio in Eq. (5), the difference is that the covariance and variance are conditional on information available at $t-1$, thus the hedge ratio is set every period and is dynamic. We use the time-varying hedge ratio to construct a new hedged portfolio. For comparison with the static strategy, we use the following measure of hedging effectiveness, E, derived by Ederington (1979):

$$
E=\frac{\sigma_{u}^{2}-\sigma_{h}^{2}}{\sigma_{u}^{2}}
$$

where $\sigma_{u}^{2}$ is the variance of the unhedged portfolio returns, i.e. the return of the ship price index, and $\sigma_{h}^{2}$ is the variance of the returns of the new hedged portfolio.

In order to extract the time-varying variances and covariances for the dynamic hedge ratios we use Engle's (2002) dynamic conditional correlation GARCH $(1,1)$ model. The GARCH $(1,1)$ specification is the most commonly used GARCH model for financial time series, based on its ability to adequately capture the dynamic of the variance

${ }^{3}$ Weekly portfolio adjustment to reflect slower moving vessel values is not very realistic. However, monthly timeseries of ship values represent averages of weekly values, which creates a mismatch with FFA prices in the time dimension. 
(Alizadeh and Nomikos 2009). This has also been shown by Kavussanos and Nomikos (2000b), who estimated dynamic hedge ratios in the freight derivatives market. We define the model in accordance with Chang et al. (2011) as follows:

$$
\begin{aligned}
& y_{t} \mid F_{t-1} \sim N\left(0, Q_{t}\right), t=1,2, \ldots, n \\
& Q_{t}=D_{t} \Gamma_{\mathrm{t}} D_{t}
\end{aligned}
$$

where $y_{t}=\left(y_{1 t}, \ldots, y_{m t}\right)^{\prime}$ is a sequence of independently and identically distributed random vectors, $F_{t-1}$ is the information available at $\mathrm{t}-1, \mathrm{~m}$ is the number of returns, $D_{t}$ $=\operatorname{diag}\left(h_{1}^{1 / 2}, \ldots, h_{m}^{1 / 2}\right)$ is a diagonal matrix of conditional variances and $\Gamma_{t}$ is the correlation matrix containing the conditional correlations. The conditional variance is defined as a univariate $\mathrm{GARCH}(\mathrm{p}, \mathrm{q})$ model as follows:

$$
h_{i t}=\omega_{i}+\sum_{k=1}^{p} \alpha_{i k} \varepsilon_{i, t-k}^{2}+\sum_{l=1}^{q} \beta_{i l} h_{i, t-l}
$$

where $\alpha_{i k}$ is the parameter of lagged squared error terms (the ARCH effect) and $\beta_{i l}$ is the lagged variance parameters (the GARCH effect). In line with Alizadeh and Nomikos (2009, p.87) we use the Maximum Likelihood method for estimating the parameters of interest, using the statistical software Stata. and used to calculate the optimal timevarying hedge ratio from Eq. (6). To compare of the hedge efficiency with the static hedge, we construct portfolios where the hedge ratio is dynamically adjusted every week. Then, we calculate the hedging effectiveness of this portfolio from Eq. (7).

\section{Data}

\section{Descriptive statistics}

Our data set consists of weekly (Friday) ship prices and FFA prices between January 7th, 2005 and December 30th, 2016, collected from the Clarkson Shipping Intelligence Network and the Baltic Exchange, respectively. The prices refer to ships in average condition, built at a first-class competitive shipyard and represent Clarksons' best estimate of what price a standard ship would have obtained in the market if transacted between a willing buyer and seller (Clarkson Research 2015). We note that the resulting timeseries of ship prices necessarily relies in part on shipbrokers' subjective assessment and may therefore be subject to measurement errors. However, the alternative - a purely transaction-based index - is difficult to generate in the sale and purchase market for ships due to low liquidity and a heterogeneous fleet. An important question from a hedging point of view is whether brokers' reliance on the last deal done has an anchoring effect on price estimates, in which case the measured ship price volatility may be lower than the true volatility, and thus potentially affect both correlations and portfolio variance.

We use FFAs settled on the global average of Capesize tripcharter rates (the so-called 4TC average) as the hedging instrument as these are known to be the most liquid contracts (Kavussanos and Visvikis 2016). Sufficient liquidity is important in the FFA market as bid-offer spreads can be substantial (Alizadeh et al. 2015). In order to match with the reporting for our weekly Clarkson ship price indices we use the closing price as of Friday, or Thursday if Friday is a non-reporting day. Based on the prices of the individual quarterly and calendar year contracts we follow Adland and Alizadeh (2018) 
and construct a two-year fixed maturity FFA portfolio by weighting each contract in accordance with the number of days within the two-year window. For instance, this implies weighting the nearest contract by the days left of the current quarter. ${ }^{4}$ Likewise, the farthest contract is weighted such that the total hedging period at any time equals 2 years. For instance, on the 3rd of February 2012 the FFA portfolio is constructed as [(Q1x58 + Q2x90 + Q3*90 + Q4*90 + CAL13*365 + CAL14x33)/730]. ${ }^{5}$

Table 1 summarizes the descriptive statistics for ship prices and corresponding annual returns. As expected, younger vessels are more expensive than older vessels, with average prices declining roughly linearly with age from USD 57.94 million for a 5-yearold vessel to USD 18.67 million for a 20 -year-old vessel. We also note the small difference between the minimum price of the 15- and 20-years-old vessels, indicating that the scrap price acts like a floor during poor markets. Importantly, the correlations between our Capesize FFA portfolio and ship prices is very high even on a return basis. The correlation to FFAs is the lowest for 20-year old vessels, implying that scrap price dynamics is somewhat more important for this vintage, as expected. We note further that the volatility of (weekly) ship price returns is an increasing function of vessel age. This reflects: 1) the greater impact of short-term freight market volatility when the remaining lifespan is short and 2) the expectation of mean reversion of freight rates, which means that long-term freight rates and the residual vessel value in the "long term" is necessarily less volatile. Thus, the value of modern tonnage will fluctuate less on a return basis.

Table 2 summarizes statistics for the 4TC average FFA contracts used in the portfolio, as well as the portfolio overall. The nearest contracts have a higher volatility than contracts far away, a pattern known as "volatility term structure" (Alizadeh and Nomikos 2009, p.168). This is in accordance with the notion of mean reversion in spot freight rates, in which case a long-term average has lower volatility than a short-term average. For the alternative - a RandomWalk process - volatility is by definition independent of maturity and time horizon.

As our sample period incorporates some of the highest spot rates ever observed in the drybulk market, the forward curve is on average backwardated. This indicates that, over the examined time period, the market tends to anticipate lower future spot rates (Alizadeh and Nomikos 2009, p.167).

Figure 1 illustrates the price development for five-year old Capesize vessels and our dayweighted FFA portfolio during our sample period., which confirms the high correlation (in levels) stated in Table 1 . The greater volatility of the FFA prices are due to the difference in the effective maturity of the two assets and the long-run mean reversion discussed above.

\section{Stationarity and co-integration}

It is well known from maritime economic theory that very low and very high freight rates cannot persist in the long run due to supply-side adjustments (Stopford 2009).

\footnotetext{
${ }^{4}$ We acknowledge that it may not be easy to exactly replicate this day-weighted portfolio, since FFAs in practice are traded in multiples of 5 days and the current-quarter contract cannot be traded beyond about the 20th day of the first month (Adland and Alizadeh 2018). However, we believe that this will have minor implications.

${ }^{5}$ Here, Q1 is the FFA price for the first quarter of 2012, Q2 is the FFA price for the second quarter of 2012, Q3 is the FFA price for the third quarter of 2012, Q4 is the FFA price for the fourth quarter of 2012, CAL13 is the FFA price for 2013 and CAL14 is the FFA price for 2014.
} 
Table 1 Ship price statistics

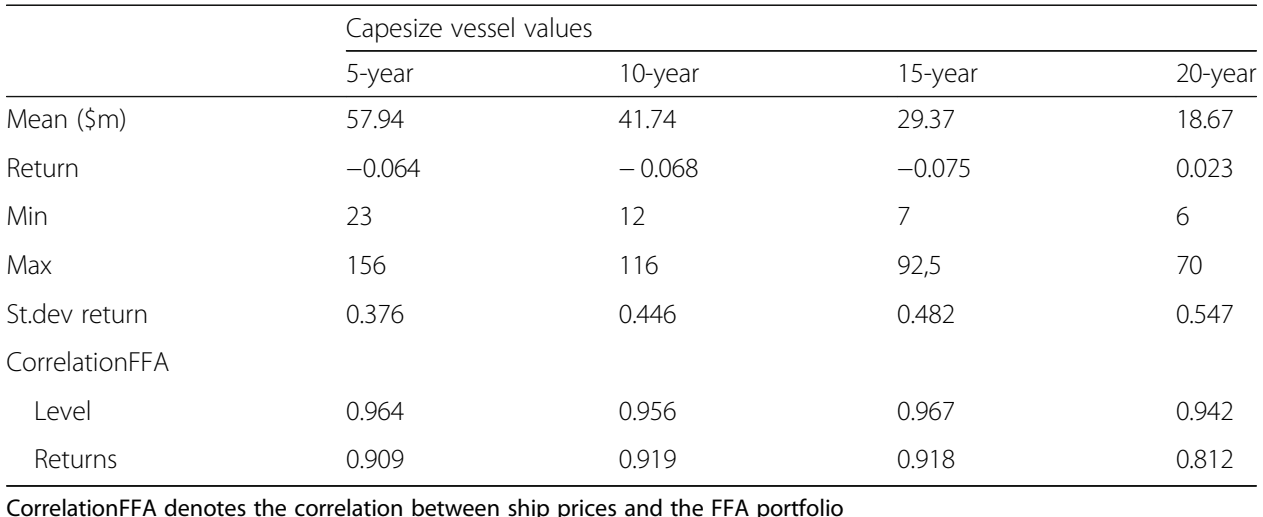

CorrelationFFA denotes the correlation between ship prices and the FFA portfolio

Consequently, spot freight rates cannot exhibit asymptotically explosive behaviour, as implied by non-stationarity (Koekebakker et al. 2006). By extension, nor can freight rate contingent claims such as ship prices and FFA prices. Nonetheless, it is often difficult empirically to reject the null hypothesis of a unit root in empirical work.

We test the time series at hand for stationarity using the Augmented Dickey-Fuller (ADF) test:

$$
\Delta y_{t}=\alpha+\beta t+\gamma y_{t-1}+\sum_{i=1}^{P} \delta_{i} \Delta y_{t-i}+\varepsilon_{t}
$$

where the change of the time series $y_{t}$ is regressed on lagged observations of itself, $y_{t-1}$, $\alpha$ is the drift component and $\delta_{i}$ are parameters on the lags of $y$ that is intended to account for any serial correlation in $\Delta y_{t}$. The null hypothesis is $y=0$, which indicates non-stationarity. We find the number of lags by minimizing the Schwarz criterion (SBIC). The level series are specified with an intercept but no trend, as the series around a non-zero value. The return series (both weekly and monthly) fluctuate around zero and have no clear trend. Hence, we specify the ADF regression without trend and intercept.

The results in Table 3 indicate that we cannot reject the null hypothesis regarding the existence of unit root in any of the level time series, which means that these series should not be used for hedging purposes in OLS (Granger and Newbold 1974). The series of weekly and monthly ${ }^{6}$ (non-overlapping) returns are clearly stationary for both ship prices and FFAs. This is in accordance with the results of both Adland et al. (2004) and Alizadeh and Nomikos (2012). Regarding yearly returns we do not have enough non-overlapping observations to draw a clear conclusion. However, the

Table 2 FFA price statistics

\begin{tabular}{|c|c|c|c|c|c|c|c|}
\hline & $\begin{array}{l}\text { Current } \\
\text { quarter }\end{array}$ & $\begin{array}{l}\text { First } \\
\text { quarter }\end{array}$ & $\begin{array}{l}\text { Second } \\
\text { quarter }\end{array}$ & $\begin{array}{l}\text { Third } \\
\text { quarter }\end{array}$ & $\begin{array}{l}\text { First } \\
\text { calendar }\end{array}$ & $\begin{array}{l}\text { Second } \\
\text { calendar }\end{array}$ & $\begin{array}{l}\text { FFA } \\
\text { portfolio }\end{array}$ \\
\hline Mean (\$) & 38,580 & 36,870 & 34,567 & 32,653 & 31,168 & 26,183 & 31,190 \\
\hline $\begin{array}{l}\text { St.dev } \\
\text { levels }\end{array}$ & 43,075 & 40,229 & 36,840 & 32,692 & 29,706 & 18,660 & 28,847 \\
\hline Min & 760 & 2975 & 3810 & 3710 & 6266 & 7900 & 5983 \\
\hline Max & 213,375 & 175,938 & 166,281 & 147,524 & 143,750 & 96,961 & 132,240 \\
\hline
\end{tabular}




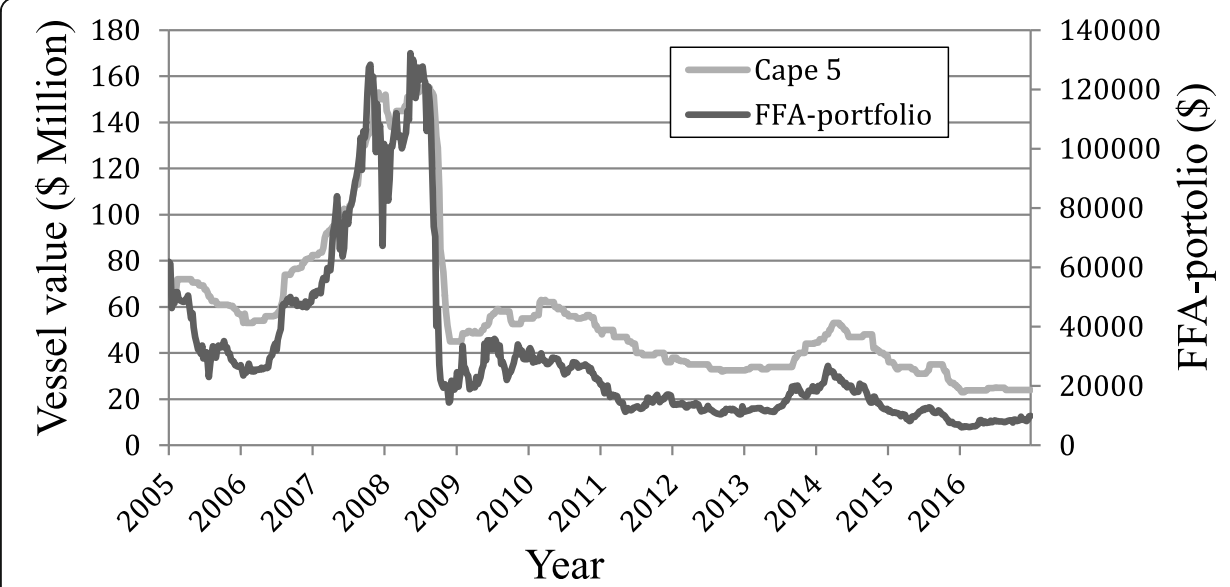

Fig. 1 Comparison between Capesize vessel price ( 5 yr old) and FFA portfolio. Source: Clarkson Research, Baltic Exchange, authors' calculations

theoretical mean reversion argument and clear stationarity of weekly and monthly returns makes it reasonable to argue that yearly returns are also stationary (Alizadeh and Nomikos 2012).

Finally, having established a theoretical relationship between ship prices and FFAs in the Theory section, we investigate this relationship empirically using the cointegration framework proposed by Engle and Granger (1987). The test results indicate a strong long-run relationship between ship prices and FFA portfolio prices for all sizes and vintages of vessels. ${ }^{7}$

\section{Empirical results}

\section{Static hedge ratio}

Table 4 shows the estimated static hedge ratio and hedging efficiency when using the FFA portfolio to hedge Capesize vessel values across the age spectrum. The hedge ratio is $0.557,0.666,0,720$ and 0.594 for the 5-, 10-, 15- and 20-year-old Capesize vessels, respectively. The regressions' $R^{2}$ are $0.824,0.842,0.841$ and 0.658 , respectively. This means that hedging $55.7 \%$ of a 5 -year-old vessel's value with the FFA portfolio leads to an $82.4 \%$ hedging efficiency in the examined time period. The FFA portfolio return is significant in explaining ship price return for all ship ages at a $1 \%$ significance level.

The hedge ratio is increasing from age 5 years to age 15 years. This is likely related to the increase in ship price volatility with age, though FFA return remains greater (on a return basis). Hence, the hedge ratio also has to increase to account for a more volatile ship price. For the 20-year old vessel this relationship changes, with a substantially lower hedge ratio.

The relatively low hedging efficiency for the 20-year-old vessels can be explained by Eq. (3), as a vessel's value is considered the sum of all (discounted) future earnings and the discounted residual value. At the end of a ship's economic lifetime, the future profits represent a smaller fraction of the value than that of a younger ship. That implies that the residual value becomes more important, however, it is not possible to

\footnotetext{
${ }^{7}$ Test results are included in the appendix. Given the clear economic relationship between FFA prices and vessel values we do not specify a model with an error-correction term.
} 
Table 3 Augmented Dickey Fuller (ADF) test

\begin{tabular}{llll}
\hline & Level & Weekly returns & Monthly returns \\
\hline Capesize vessel values & & & \\
5-year & -2.01 & -7.27 & -4.84 \\
10-year & -1.97 & -8.46 & -5.08 \\
15-year & -1.87 & -8.31 & -5.13 \\
20-year & -2.15 & -8.65 & -5.78 \\
FFA & & & -5.93 \\
Portfolio & -2.06 & -8.79 & - \\
\hline
\end{tabular}

The table shows the ADF test statistic for the series in level, weekly returns and monthly returns. The weekly returns are the first difference of the level series. The $5 \%$ critical value for the ADF is -2.860 for the level series and -1.950 for the return series

hedge this aspect with FFAs. The reason that the hedging efficiency is nevertheless quite high could be that the FFA portfolio is correlated with the scrap value (Alizadeh and Nomikos 2009).

While the optimal hedge ratio is set ex post, the hedging efficiency is a measure of the futures' potential for reducing risk. This variance reduction is only achieved if the hedge ratio used equals the optimal hedge ratio ex post. This proposes a problem for hedgers who need to decide their hedge ratios ex ante. We test the robustness of the estimates by conducting an out-of-sample test, i.e. whether the optimal hedge ratio from one period performs well in the subsequent period. The out-of-sample hedging performance, shown in Table 5, is lower in all cases compared to the in-sample results though remain highly respectable.

These results indicate that the optimal hedge efficiency and ratio is relatively stable between the two periods, at least for the youngest vessels. It is worth keeping in mind that the variance is higher in the first period (2005-2009), as this was the period leading up to and during the financial crisis, while the out-of-sample period (2009-2016) coincides with the less volatile post-financial crisis period.

\section{Dynamic hedge ratio and efficiency}

The dynamic hedge efficiencies calculated using the GARCH model are summarized in Table 6. Interestingly, the dynamic hedge ratio underperforms the static hedge in terms

Table 4 Hedge ratio and efficiency across vessel age

\begin{tabular}{lllll}
\hline & 5 -year & 10 -year & $15-$ year & 20-year \\
\hline FFA hedge ratio & $0.557^{* * *}(51.80)$ & $0.667^{* * *}(55.22)$ & $0.721^{* * *}(54.98)$ & $0.594^{* * *}(33.16)$ \\
Constant & $-0.090^{* * *}(-13.58)$ & $-0.099^{* * *}(-13.29)$ & $-0.110^{* * *}(-13.39)$ & $-0.085^{* * *}(-7.72)$ \\
No. obs. & 574 & 574 & 574 & 574 \\
Hedging efficiency $\left(R^{2}\right)$ & 0.824 & 0.842 & 0.841 & 0.658 \\
F & 2682.8 & 3049.0 & 3022.7 & 1099.8 \\
Breusch-Godfrey & $466.42[0.00]$ & $451.36[0.00]$ & $449.60[0.00]$ & $521.75[0.00]$ \\
White test & $26.21[0.00]$ & $21.99[0.00]$ & $71.51[0.00]$ & $141.95[0.00]$
\end{tabular}

$P$-values in [] and standard errors in (). ${ }^{* *}$ indicate significance at the $1 \%, 5 \%$ and $10 \%$ level, respectively. Standard errors are corrected for serial correlation and heteroskedasticity using Newey and West (1987) method. The F-test is a measure of the goodness of fit when comparing models. The Breusch-Godfrey serial correlation LM test is a test for autocorrelation in the errors in a regression model. The White test establishes whether the errors are homoscedastic 
Table 5 Out-of-sample hedge performance

\begin{tabular}{lll}
\hline Vessel age & Hedge ratio & Out-of-sample \\
\hline 5 -year & 0.531 & $72.4 \%$ \\
10 -year & 0.645 & $73.1 \%$ \\
15 -year & 0.771 & $66.6 \%$ \\
20-year & 0.639 & $40.3 \%$ \\
\hline
\end{tabular}

of hedging efficiency despite the superior statistical properties of the GARCH model compared to the simple OLS model. This is a common result also for other commodities such as for wheat futures (Myers 1991) and soybeans (Garcia et al. 1995). However, it might be that other dynamic model specifications are more appropriate for our data than the GARCH $(1,1)$ model. Hence, we cannot conclude that dynamic hedge ratios in general underperform the static hedge ratio in hedging vessel values.

The optimal dynamic hedge ratio for a five-year-old vessel is presented as an example in Fig. 2, together with the optimal (ex-post) static hedge ratio for comparison. The conditional hedge ratio is clearly changing as new information arrives in the market. We note that the dynamic hedge model sometimes suggests negative hedge ratios, that is, effectively increasing exposure to the shipping markets through adding long FFAs positions to an existing "long vessel" position as a shipowner. This is simply a result of negative covariance over certain windows in our rolling sample for dynamic hedge ratio estimation. While FFA prices and second-hand values are co-integrated in the long run, co-integration does not preclude short-term deviations or indeed price moves in opposite directions.

\section{Concluding remarks}

In this paper we have revisited the theoretical relationship between vessel values and a freight derivatives portfolio to show that ship price exposure should be hedged with a fixed-maturity portfolio of FFA contracts covering as much of the vessel's lifespan as possible. We also highlight how solutions adopted in the literature, using a single FFA contract for hedging, creates artificial jumps in the volatility of the hedging instruments at the time of rollovers, which will affect hedge ratios. We also show, based on maritime economic theory, that there is a relationship between the vessel age (i.e. remaining lifespan) and the ability of FFA contracts to hedge vessel values. Our empirical estimates of the optimal hedge ratios and hedging efficiency across vessel ages suggest that the hedge ratio is generally increasing with vessel age, except for vessels beyond 15 years of age. This is a new result in the limited ship hedging literature.

We note that the true hedging efficiency can differ from the results obtained here. Firstly, we do not account for physical basis risk between the actual vessel or fleet or vessels being hedged and the standard "Baltic type" vessel underlying FFA contracts.

Table 6 Comparison of static and dynamic hedge efficiency

\begin{tabular}{llr}
\hline Vessel age & Dynamic & Static \\
\hline 5 -year & $77.4 \%$ & $82.4 \%$ \\
10 -year & $61.5 \%$ & $84.2 \%$ \\
15 -year & $79.9 \%$ & $84.1 \%$ \\
20 -year & $68.5 \%$ & $65.8 \%$ \\
\hline
\end{tabular}




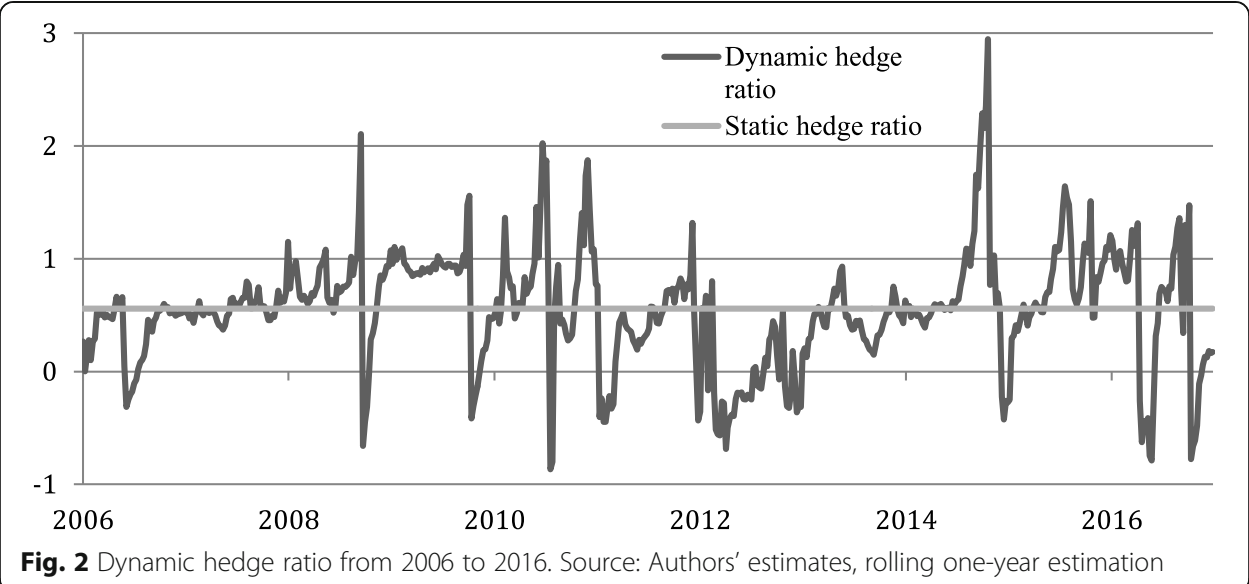

Such physical basis risk includes but is not limited to differing technical specifications, attractiveness in the second-hand market and the impact of low liquidity on pricing. Secondly, we only consider the hedging of returns attributable to changes in vessel values and not the overall return from vessel ownership, which also includes earnings (potentially negative) from operation. Including earnings from operation would increase the volatility of returns from ship ownership (they are pro-cyclical) and likely also the correlation with FFA returns (as freight rates are highly positively correlated with FFA prices). The overall effect should, thus, be an increase in both the hedge ratio and the hedge efficiency.

In terms of further work, it would be interesting to investigate how different dynamic model specifications can compete against the static optimal hedge ratio.

\section{Appendix}

Table 7 Engle-Granger Co-integration test results

\begin{tabular}{lr}
\hline & Level \\
\hline Capesize & \\
5 -year & -6.56 \\
10 -year & -4.93 \\
15 -year & -6.59 \\
20-year & -4.81 \\
\hline
\end{tabular}

The table shows the ADF test statistic for the series in level, weekly returns and monthly returns. The weekly returns are the first difference of the level series. The ADF regressions are specified without trend for the level series, and without trend and intercept for the both of the return series. The lag length is determined by the SBIC. The $5 \%$ critical value for the ADF is -2.860 for the level series and -1.950 for the return series

Table 8 Bootstrap results

\begin{tabular}{lllll}
\hline & FFA port. & Constant & R2 & F \\
\hline Capesize & & & & \\
5 -year & $0.544^{* * *}(0.003)$ & $-0.088^{* * *}(0.002)$ & 0.784 & 36,322 \\
10 -year & $0.648^{* * *}(0.003)$ & $-0.098^{* * *}(0.002)$ & 0.796 & 38,920 \\
15 -year & $0.704^{* * *}(0.003)$ & $-0.110^{* * *}(0.002)$ & 0.799 & 39,729 \\
20-year & $0.583^{* * *}(0.005)$ & $-0.085^{* * *}(0.003)$ & 0.628 & 16,871 \\
\hline
\end{tabular}

Figures in () are standard errors. FFA denotes the bootstrapped FFA-portfolio, Con. is the constant. ${ }^{* * * i n d i c a t e ~ s i g n i f i-~}$ cance at the $1 \%, 5 \%$ and $10 \%$ level, respectively. The bootstrap series is constructed by 10,000 realizations of nonoverlapping 52-week returns based on the stationary bootstrap of Politis and Romano (1994) 


\section{Acknowledgements}

The authors would like to thank two anonymous referees for their assistance in improving earlier versions of this paper. All remaining errors are our own.

\section{Authors' contributions}

HA and EAB performed all empirical tests and data work as part of their master thesis. RA made substantial editing to the text for length and content, made two revisions to the paper in accordance with referee feedback and submitted the final version. All authors read and approved the final manuscript.

\section{Funding}

No funding was received for the research.

\section{Availability of data and materials}

The data that support the findings of this study are available from Clarkson Research and the Baltic Exchange but restrictions apply to the availability of these data, which were used under license for the current study, and so are not publicly available.

\section{Competing interests}

The authors declare that they have no competing interests.

Received: 22 April 2019 Accepted: 4 December 2019

Published online: 31 December 2019

\section{References}

Adland R, Alizadeh A (2018) Explaining price differences between physical and derivative freight contracts. Transp Res E 118: 20-33

Adland R, Cullinane K (2006) The non-linear dynamics of spot freight rates in tanker markets. J Transport Res E 42(3):211-224 Adland R, Jia H (2017) Simulating physical basis risks in the Capesize freight market. Marit Econ Logist 19(2):196-210

Adland R, Jia H, Koekebakker S (2004) The pricing of forward ship value agreements and the unbiasedness of implied forward prices in the second-hand market for ships. Marit Econ Logist 6(2):109-121

Alexandridis G, Sahoo S, Visvikis I (2017) Economic information transmissions and liquidity between shipping markets: new evidence from freight derivatives. Transport Res E Logist Transport Rev 98:82-104

Alizadeh A, Nomikos N (2009) Shipping derivatives and risk management. Basingstoke: Palgrave Macmillian

Alizadeh AH, Kappou K, Tsouknidis D, Visvikis I (2015) Liquidity effects and FFA returns in the international shipping derivatives market. Transp Res E 76:58-75

Alizadeh AH, Kavussanos MG, Menachof DA (2004) Hedging against bunker price fluctuations using petroleum futures contracts: constant versus time-varying hedge ratios. Appl Econ 36(12):1337-1353

Alizadeh AH, Nomikos NK (2007) Investment timing and trading strategies in the sale and purchase market for ships. Transp Res B Methodol 41(1):126-143

Alizadeh AH, Nomikos NK (2011) Dynamics of the term structure and volatility of shipping freight rates. J Transp Econ Policy 45(1):105-129

Alizadeh AH, Nomikos NK (2012) Ship finance: hedging ship price risk using freight derivatives. In: Talley W (ed) Blackwell companion to maritime economics. Chichester: Wiley, pp 433-451

Alizadeh AH, Thanopoulou H, Yip TL (2017) Investors' behavior and dynamics of ship prices: a heterogeneous agent model. Transport Res E Logist Transport Rev 106:98-114

Baillie RT, Myers RJ (1991) Bivariate GARCH estimation of the optimal commodity futures hedge. J Appl Econ 6(2):109-124

Beenstock M (1985) A theory of ship prices. Marit Policy Manag 12(3):215-225

Beenstock M, Vergottis A (1989a) An econometric model of the world market for dry cargo freight and shipping. Appl Econ 21(3):339-356

Beenstock M, Vergottis A (1989b) An econometric model of the world tanker market. J Transp Econ Policy 23(3):263-280

Bollerslev T (1986) Generalized autoregressive conditional heteroskedasticity. J Econ 31(3):307-327

Bollerslev T, Chou R, Kroner K (1992) ARCH Modelling in finance. J Econ 52(1):5-59

Campbell J, Viceira L (2005) The term structure of the risk-return trade-off. Financ Anal J 61(1):34-45

Chang C-L, McAleer M, Tansuchat R (2011) Crude oil hedging strategies using dynamic multivariate GARCH. Energy Econ 33(5):912-923

Clarkson Research, 2015, Sources and methods for the shipping intelligence weekly, www.clarksons.net

Clarkson Research, 2016, Clarksons Research Wordpress. Retrieved May 2018, from https://clarksonsresearch.wordpress.com/ tag/scrap-value/

Ederington $L$ (1979) The hedging performance of the new futures markets. J Financ 34(1):157-170

Engle R (1982) Autoregressive conditional heteroscedasticity with estimates of the variance of United Kingdom inflation. Econometrica 50(4):987-1007

Engle R, Granger C (1987) Co-integration and error correction: representation, estimation, and testing. Econometrica 55(2): $251-276$

Engle, R. (2002). Dynamic conditional correlation: A simple class of multivariate generalized autoregressive conditional heteroskedasticity models. Journal of Business \& Economic Statistics, 20(3), 339-350.

Garcia P, Roh JS, Leuthold RM (1995) Simultaneously determined, time-varying hedge ratios in the soybean complex. Appl Econ 27(12):1127-1134

Goulas L, Skiadopoulos G (2012) Are freight futures markets efficient? Evidence from IMAREX. Int J Forecast 28(3):644-659

Granger C, Newbold P (1974) Spurious regressions in econometrics. J Econ 2(2):111-120

Haralambides HE (1992) Freight futures trading and shipowners' expectations. In: $6^{\text {th }}$ world conference on transport research (WCTR) conference proceedings, Lyon, France, pp 1411-1422 
Haralambides HE, Tsolakis SD, Cridland C (2005) Econometric modelling of newbuilding and secondhand ship prices. Res Transp Econ 12:65-105

Johansen S (1988) Statistical analysis of cointegration vectors. J Econ Dyn Control 12(2-3):231-254

Kalouptsidi M (2014) Time to build and fluctuations in bulk shipping. Am Econ Rev 104(2):564-608

Kavussanos M, Visvikis I (2016) The international handbook of shipping finance: theory and practice. Palgrave Macmillan, London

Kavussanos MG (1996) Comparisons of volatility in the dry-cargo ship sector: spot versus time charters, and smaller versus larger vessels. J Transp Econ Policy 30(1):67-82

Kavussanos MG (1997) The dynamics of time-varying volatilities in different size second-hand ship prices of the dry-cargo sector. Appl Econ 29(4):433-443

Kavussanos MG, Nomikos NK (1999) The forward pricing function of the shipping freight futures market. J Futur Mark 19(3): 353-376

Kavussanos MG, Nomikos NK (2000a) Hedging in the freight futures market. J Deriv 8(1):41-58

Kavussanos MG, Nomikos NK (2000b) Constant vs. time-varying hedge ratios and hedging efficiency in the BIFFEX market. Transport Res E Logist Transport Rev 36(4):229-248

Kavussanos MG, Nomikos NK (2003) Price discovery, causality and forecasting in the freight futures market. Rev Deriv Res 6(3): 203-230

Kavussanos MG, Visvikis ID (2006) Derivatives and risk management in shipping. Witherby Seamanship International, London Kavussanos MG, Visvikis ID (2008) Hedging effectiveness of the Athens stock index futures contracts. Eur J Financ 14(3):243270

Kavussanos MG, Visvikis ID (2010) The hedging performance of the Capesize forward freight market. In: International handbook of maritime business. Cheltenham: Edward Elgar Publishing

Kavussanos MG, Visvikis ID, Menachof D (2004) The unbiasedness hypothesis in the freight forward market: evidence from cointegration tests. Rev Deriv Res 7(3):241-266

Koekebakker S, Adland R, Sodal S (2006) Are spot freight rates stationary? J Transp Econ Policy 40(3):449-472

Kou Y, Luo M (2015) Modelling the relationship between ship price and freight rate with structural changes. J Transp Econ Policy (JTEP) 49(2):276-294

Kroner K, Sultan J (1993) Time-varying distributions and dynamic hedging with foreign currency futures. J Financ Quant Anal 28(4):535-551

Modigliani F, Miller MH (1958) The cost of capital, corporation finance and the theory of investment. Am Econ Rev 48(3):261297

Myers R (1991) Estimating time-varying optimal hedge ratios on futures markets. J Futur Mark 11(1):39-53

Newey WK, West KD (1987) A simple, positive semi-definite, heteroskedasticity and autocorrelation consistent covariance matrix. Econometrica 55(3):703-708

Politis DN, Romano JP (1994) Large sample confidence regions based on subsamples under minimal assumptions. Ann Stat 22(4):2031-2050

Smith CW, Stulz RM (1985) The determinants of firms' hedging policies.J Financ Quant Anal 20(4):391-405

Stevens N (1976) A mortgage futures market: its development, uses, benefits, and costs. Federal Reserve Bank of St. Louis. Review, April 12 - 19.

Stopford M (2009) Maritime economics. Routledge, London

Strandenes SP (1984) Price determination in the time charter and second hand markets. Center for Applied Research, Working paper MU 6, Bergen: Norwegian School of Economics and Business Administration

Strandenes SP (1986) NORSHIP - a simulation model of markets in bulk shipping. Discussion paper 11, Bergen: Norwegian School of Economics and Business Administration

Thuong LT, Visscher SL (1990) The hedging effectiveness of dry-bulk freight rate futures. Transp J 8(1):58-65

Tsolakis SD, Cridland C, Haralambides HE (2003) Econometric modelling of second-hand ship prices. Marit Econ Logist 5(4): $347-377$

Yin J, Luo M, Fan L (2017) Dynamics and interactions between spot and forward freights in the dry bulk shipping market. Marit Policy Manag 44(2):271-288

\section{Publisher's Note}

Springer Nature remains neutral with regard to jurisdictional claims in published maps and institutional affiliations.

\section{Submit your manuscript to a SpringerOpen ${ }^{\circ}$ journal and benefit from:}

- Convenient online submission

Rigorous peer review

- Open access: articles freely available online

- High visibility within the field

- Retaining the copyright to your article

Submit your next manuscript at $\boldsymbol{\nabla}$ springeropen.com 